UDC: $159.923: 159.924 .7$

DOI: https://doi.org/10.24195/2414-4665-2017-1-8

\author{
Mahboubeh Razmjouyi, \\ Department of Counselling, Islamic Azad University, \\ Marvdasht Branch, Marvdasht, Iran. \\ Zhaleh Refahi, \\ Department of Counselling, Islamic Azad University, \\ Marvdasht Branch, Marvdasht, Iran. \\ Nadereh Sohrabi, \\ Department of Psychology, Islamic Azad University, \\ Marvdasht Branch, Marvdasht, Iran.
}

\title{
INVESTIGATION OF THE MEDIATING ROLE OF SELF-ASSERTIVENESS IN THE RELATIONSHIP BETWEEN COGNITIVE EMOTION REGULATION AND MARITAL ADJUSTMENT
}

This study aims to explore the mediating role of self-assertiveness for cognitive emotion regulation and marital adjustment. The carried out experiment involved 205 respondents (165 male \& 38 female) aged from 22 to 55 years who were selected by cluster sampling method. In order to collect the data, the Assertiveness Questionnaire of Shilton and Broughton (1993), the Cognitive Emotion Regulation questionnaire of Garnefski (2001) and Dyadic Adjustment Scale (DAS) of Spanier (1976) were used. The research results have proved the mediating role of the variable of "assertiveness" for cognitive emotion regulation and marital adjustment. Cognitive positive and negative emotional regulation through self-assertiveness has both direct and indirect effects on the marital adjustment. The variable of selfassertiveness has a significant mediating role for cognitive emotion regulation and marital adjustment. According to the research results, it is recommended for counselling centers to use workshops and trainings of assertiveness to promote the marital adjustment of couples. Besides, family welfare counselling centers should implement positive emotion regulation trainings to enhance the marriage compatibility.

Keywords: assertiveness, cognitive emotion regulation, marital adjustment.

\section{Introduction}

Marriage is a sacred union that which has been existing in all nations and most religions throughout lifetime. It is considered as a human ideal kind of relationship because it is a fundamental structure to establish family relationships and sincerity. A good marriage gives meaning and identity to the life (Rosen et al. 2004). Several factors are involved in marital life and the basic requirement in this important issue is the adaptability to stressful situations. The ability to adjust to various situations is not a simple task in the era of stress and rapid social changes. The hostile relations between the spouses affect the mental and physical health of couples (Keicoat Janice, 2005, Rios, 2010). The concept of marital adjustment has gained a particular significance in the study of marriage and family relations. It has a major impact on the duration of marriage and is focused on a psychological sphere where married people control the conflicts and cope with each other's problems. In general, it is believed that internal and interpersonal factors are significant in marital satisfaction (Perlman, 1987). In recent years, health psychology has placed a great importance on the manner to deal with stress and life challenges in improving physical, psychological and social health of individuals. It considers the strengthening of coping responses and empowering of cognitive emotion regulation as the best approaches to cope with stress and life challenges (Alloy and Riskind, 2006). Emotional regulation refers to the processes by which we experience our emotions and express them (Szczygie Buczny \& Bazinska, 2012) and it involves a number of regulatory processes like experiencing the thrill, physiological, social and behavioural reactivity and cognitive processes (Zolomiki \& Haun, 2010). Fredrickson (2002) found during his research that selfassertive girls are less likely to be lonely in the middle age, they have a greater marital satisfaction, experience less stress, rarely get divorced, they retain their marriage compatibility because they cope effectively with the conflicts in their relationship.

Therefore, this research aims to reveal the relationship between cognitive emotion regulation and marital adjustment by testing the role of self-assertiveness.

Theoretical fundaments of research

Marital adjustment and effective factors

Adaptation of couples is one of the successful consequences that not only affects their satisfaction and feeling of happiness, but also reduces marital problems. Given the importance of marital adjustment in family health and finally the balance of family and also the importance of a successful marriage with well-being that is the source and origin of marital adjustment and mental balance (Karimi, 2007) in everyday life of adjusted couples, there exists a dynamism that prevents negative thoughts and feelings about each other. Theses couples have intelligent and emotional marital lives (Adibnia, 2012). Studies show that couples with high marital compatibility have higher 
self-esteem and are more compatible in social relationships (Mollazadeh, 2002).

\section{Cognitive emotion regulation}

Emotional regulation refers to the process by which we experience our emotions and express them (Szczygie Buczny \& Bazinska, 2012); it includes a number of regulatory processes like experiencing the thrill, physiological, social and behavioural reactivity and cognitive processes (Szczygiel, Buczny \& Bazinska, 2012). According to previous studies, cognitive emotion regulation strategies include the following nine different strategies that people apply cognitively while experiencing the threatening and stressful life events, before they really accomplish a task:

\section{Self-blame}

This strategy is based on blaming oneself for the negative events that have happened (Bulman, 1979).

\section{Blaming others}

This strategy refers to the practice of blaming others because of a negative event that has occurred.

\section{Acceptance}

Using this strategy, a person gets along with what has happened, it means that the person has accepted the reality about negative and stressful events (Garnefski, Kraaij, 2006).

\section{Planning}

This strategy is based on thinking about the ways to cope with stressful situations. The person thinks about what steps should be taken and how he/she can successfully cope with problems (Garnefski, Kraaij, 2006).

\section{Positive refocusing}

This strategy refers to thinking about the positive and pleasant experiences rather than thinking about the real events in adverse conditions (Garnefski, Kraaij, 2006).

\section{Positive reappraisal}

The strategy of positive reappraisal refers to making positive conclusions out of negative events and considering them as the experience for personal growth (Jermann et al. 2006).

\section{Development of prospects}

This strategy refers to reducing the importance of the experienced event with an emphasis on its relativity compared to other events (Garnefski, Kraaij, 2006).

\section{Making disastrous}

This strategy refers to the thoughts that emphasize the terrible negative event and experiencing it (Ghafrani, 2012).

\section{Rumination}

Thinking plays an important role in this strategy. But thinking does not have a positive role and what really exists is just negative thinking (Garnefski, Kraaij, 2006).

\section{Assertiveness and self-expression}

Assertiveness is placed between two categories of non-assertive behaviour: passive and aggressive behaviours. There exist two useful and concise definitions for assertiveness (Khanzadeh et al. 1386):

A: The assertiveness is the realization of one's rights and expressing one's thoughts, feelings and beliefs in a proper, direct and honest manner in such a way to respect the rights of others.

B: The assertiveness is a behaviour that enables a person to act in his/her favour and have a self-reliant behaviour without any anxiety; it helps him/her to express honestly his/her true feelings and acquire his/her rights with respect to the rights of others.

\section{$A$ review of the research background}

Ongen (2010), Zlomke \& Hahn (2010), Kereste \& Vanden Komer (2004), Garnefski et al. (2002) showed in their studies that women are more likely than men to use the rumination strategy. Individuals, especially women, apply the rumination strategy for understanding and recognition of their distress. Rumination enhances the negative thoughts, so it can lead to depression and anxiety (Aldao, Nolen \& Hoeksema, 2010).

Kooterla, Dy'er \& Stilezr (2010) conducted an investigation on the training of Spanish couples and the results showed that workshops had positive impact on their marital adjustment. This study that investigated the components of positive communications, conflict resolution, negative interactions and the commitment in the relationship has shown that the less extent of commitment in the relationship causes the greater extent of negative interactions. Rershaw, Blais \& Smith (2010) in the study titled "The negative influence of anger on marital satisfaction: the importance of protection and anger of spouse" showed that marital satisfaction has an inverse correlation with neurotic behaviours. In this study, the individual and collective effects of anxiety, anger and depression affecting marital satisfaction were investigated on the sample of 301 couples. The results have shown that depression and anxiety have similar negative and individual impacts on marital satisfaction but the anger has a common negative impact on couples. It means that the anger has more relationship with marital discord.

Oprisan \& Cristae (2012) showed in their study that regardless of the duration of the marriage, the ability to communicate appropriately, high self-esteem of couples and happiness of couples are effective on their perception of marital adjustment. Vibha, Saddichha, Khan \& Akhtar (2013) conducted a research of the life quality and marital adjustment of three categories of patients including depression, bipolar disorder and schizophrenia patients discharged from hospital. They concluded that marital adjustment in schizophrenic patients has a significant difference with two other diseases; there is a direct relationship between life quality and marital adjustment. Galhardo, Gunha, Matos (2013) conducted the research entitled "The mediating role of cognitive emotion regulation on the stress related to infertility in women and men". They concluded that self-blaming in women due to their infertility reduces the marriage compatibility.

\section{Methods}

Purpose and hypothesis

This is a descriptive-correlational research with modelling approach and aims to investigate if the factor of assertiveness as a mediator variable can affect the rela- 
tionship between cognitive emotion regulation and marital adjustment.

Research hypothesis: The variable of assertiveness plays a mediating and significant role for the variables of cognitive emotion regulation and marital adjustment.

\section{Statistical population and samples}

The statistical population of this study consists of all employees of agriculture department of Shiraz in 1392 1393 (2013-2014) with an overall number of 723 (151 women and 572 men). The sample consists of 205 married men and women who were selected by cluster sampling method.

\section{Data collection}

The following questionnaires were used to collect the data in this study:

\section{Spanier's Dyadic Adjustment Scale (DAS)}

Dyadic adjustment scale is a tool that is used extensively in researches of marital lives. This questionnaire has been developed by Graham B. and Spanier (1976) in order to assess the quality of the marital relationship or other types of relationships similar to that. It was translated by Hassanshahi (2008). Spanier (1976) provided the structure of this scale based on the differences between the scores of compatible and incompatible couples (Mollazadeh, 2002). He has obtained a reliability of $96 \%$ through Cronbach's alpha for this scale.

\section{Assertiveness Questionnaire (Shilton and}

\section{Broughton, 1993)}

This questionnaire has 18 items that have 3 point Likert scale (Always, sometimes, never). The scoring method in SPSS software was considered as 0,2,1 and its reverse questions are the questions $7,9,16,17,18$. A respondent can obtain a score in the range of 0 and 36 . It means that a person with the score of 36 has a high level of assertiveness. Akbari (2011) has obtained Cronbach's alpha of 0.59 in a study for determining the reliability of this questionnaire.

\section{(CERQ)}

\section{Cognitive Emotion regulation Questionnaire}

It is one of the most respected assessment tools for measuring various cognitive strategies. This scale has been developed by Garnefski et al. (2002). The validity of this questionnaire has been tested by Samani (2010). In this study, retest results are with one-week interval for the subscales of the questionnaire in the range of 0.75 and 0.88 and the alpha coefficient for negative adjustment factors was equal to 0.74 and for positive factor, it was equal to 0.90 . The correlation of negative regulation factors with the questionnaire of DAS was equal to 0.54 and the correlation of positive regulation factors was equal to -0.30 (Samani \& Sadeghi, 2010).

\section{Data analysis}

In the dimension of data descriptive statistics, the analysis method includes using mean, standard deviation and Pearson's correlation matrix and in the dimension of inferential statistics, the statistical method of path analysis was used. The path model and a variety of fitness indices and impact factors were calculated and investigated by AMOS software.

\section{Research findings}

Research hypothesis: Assertiveness has a significant mediating role in the relationship between cognitive emotion regulation and marital adjustment.

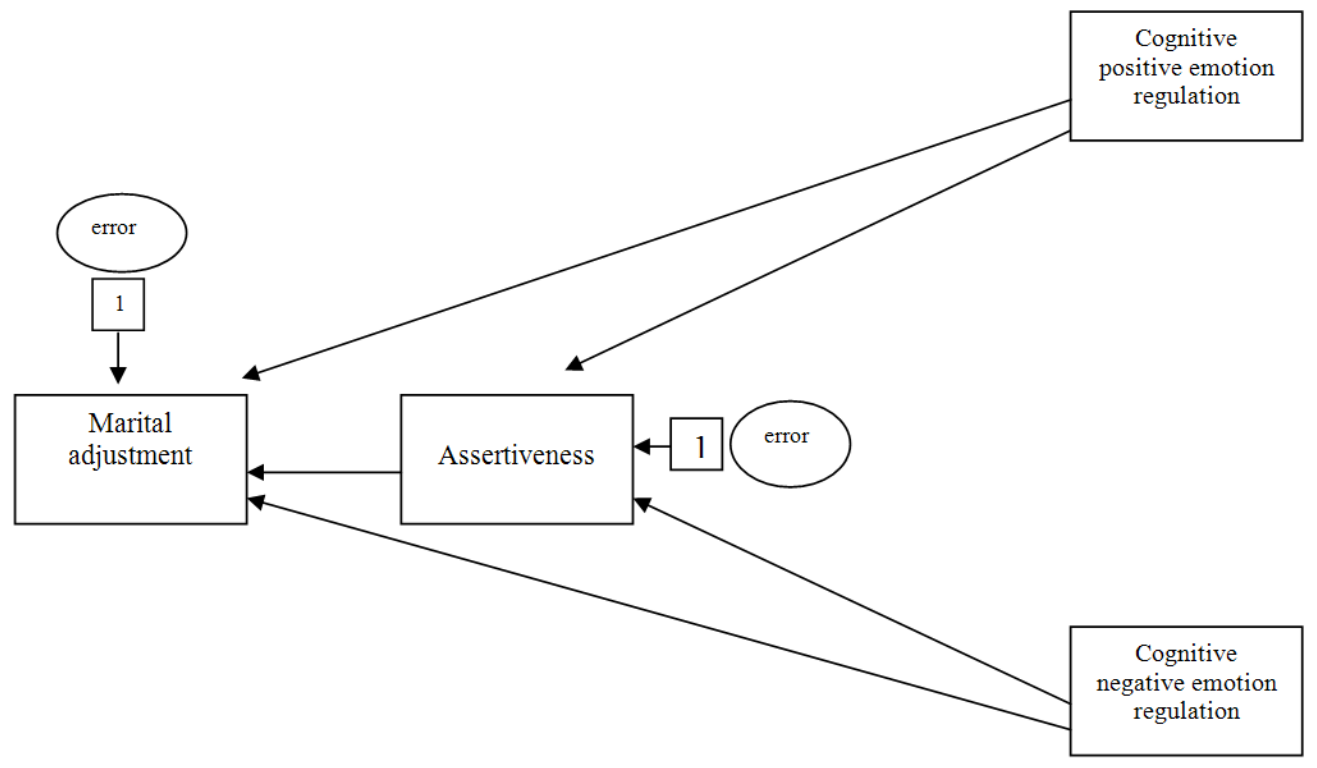

Pic. 1. The developed path model (supposed)

For testing the hypothesis (model), the statistical method of path analysis was used. For this purpose, raw data related to variables were converted to variancecovariance matrix and then the developed path model was drawn using Amos software. The generalities (various types of fitness) and details (impact coefficients) of the model were calculated and investigated as follows. The 
results of calculations and estimation of parameters of developed path model can been seen in Pic. 2 .

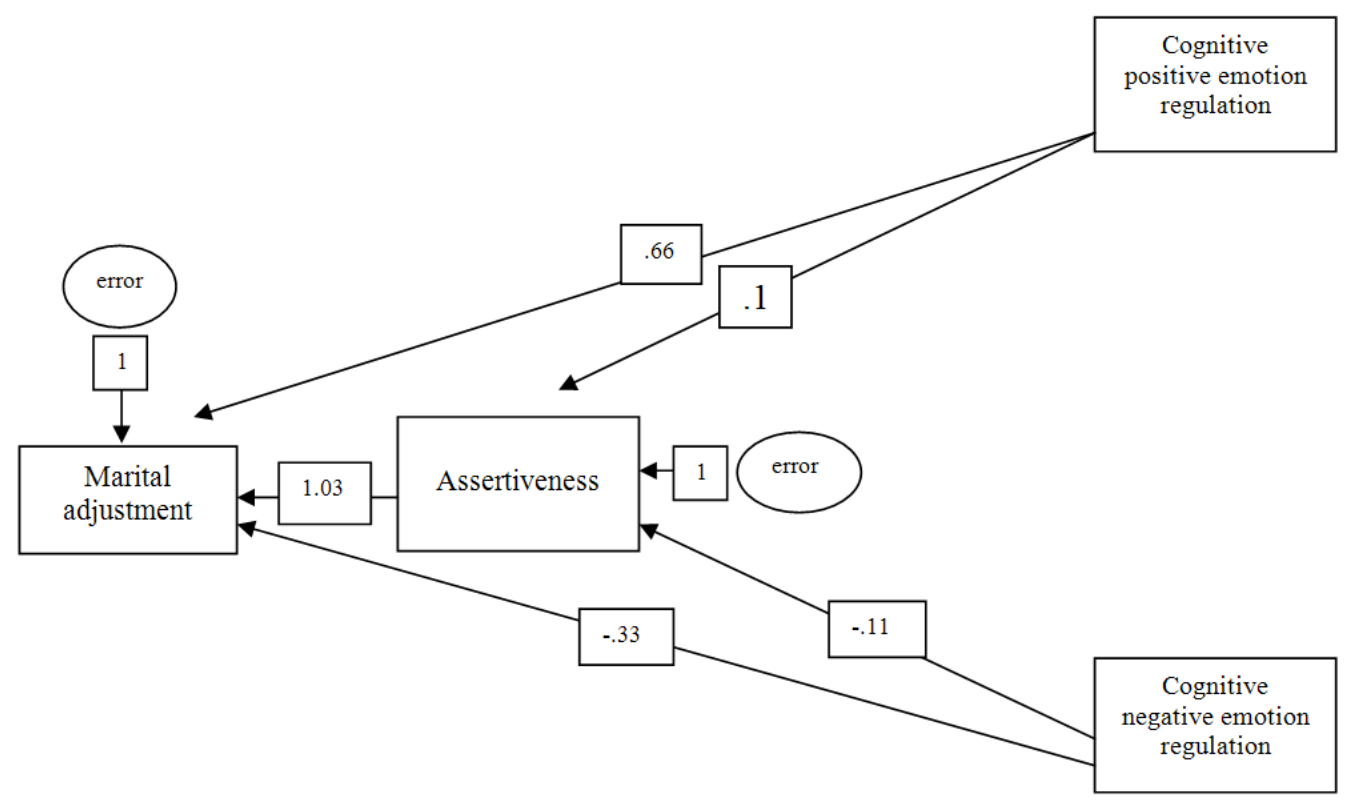

Pic. 2. The developed path model (supposed) with estimated values

Note: The error variance values are not mentioned in the model. The regression weight of all variables of Syntax error has been fixed to 1 by default using Amos software.

For investigating the details of the model, the reported values for parameters and the significance of their difference with zero (especially for impact coefficients) were used. The results are shown in Table 1.

Calculations of regression weight (impact coefficients) of the developed model

Table 1.

\begin{tabular}{|l|l|l|l|l|}
\hline Path & Estimate & Appropriate standard error & Critical Ratio & Significance level \\
\hline $\begin{array}{l}\text { Cognitive positive } \\
\text { emotion regulation } \\
\text { Assertiveness }\end{array}$ & 0.990 & 0.028 & 3.575 & 0.000 \\
\hline $\begin{array}{l}\rightarrow \text { Cognitive negative } \\
\text { emotion regulation } \rightarrow \\
\text { Assertiveness }\end{array}$ & -0.115 & 0.033 & & -3.426 \\
\hline $\begin{array}{l}\text { Assertiveness } \rightarrow \text { Marital } \\
\text { adjustment }\end{array}$ & 1.030 & 0.310 & 3.318 & 0.000 \\
\hline $\begin{array}{l}\text { Cognitive positive } \\
\text { emotion regulation } \rightarrow \\
\text { Marital adjustment }\end{array}$ & 0.656 & 0.126 & 5.228 & 0.000 \\
\hline $\begin{array}{l}\text { Cognitive negative } \\
\text { emotion regulation } \rightarrow \\
\text { Marital adjustment }\end{array}$ & -0.326 & 0.152 & & 0.000 \\
\hline
\end{tabular}

According to the Table 1, all impact coefficients have significant differences with zero. It can also be seen that cognitive positive and negative emotion regulation through the assertiveness have direct and indirect impact on marital adjustment. Furthermore, by comparing the coefficient of direct impact of cognitive positive and negative emotion regulation on marital adjustment with the coefficients of indirect impact of cognitive positive and negative emotion regulation through the assertiveness, it appears that assertiveness has a significant mediating role in the relationship between cognitive emotion regulation and marital adjustment. In general, these results indicate the validity of the developed model and confirm the hypothesis of this study.

\section{Discussion and conclusion}

Chi-square value is not significant and this fact shows that statistically, there is no significant difference between the observed variance-covariance matrix and the reproduced variance-covariance matrix and this indicates the desirability of the fit index of two developed models and the acceptability of the model. The comparative fit index, Tucker-Lewis Index, normalized fit index, Relative 
Fit Index and Incremental Fit Index were calculated and the obtained results indicated that all comparative indices show acceptable values and this fact indicates a very good fitness of data to the developed model. All impact coefficients have significant difference with zero. Also it can be seen that cognitive positive and negative emotion regulation have direct and indirect impacts on the marital adjustment through the factor of assertiveness. Furthermore, by comparing the impact coefficient of direct impact of cognitive positive and negative emotion regulation on marital adjustment with impact coefficients of the indirect impact of cognitive positive and negative emotion regulation on marital adjustment through the assertiveness, it becomes clear that the assertiveness has a significant mediating role in the relationship between cognitive emotion regulation and marital adjustment. These results indicate the validity of the developed model and confirm the hypothesis of this study.

These obtained results are consistent with the research results of Hulbert, Apt \& Robehl (1993), Ronnan \& Deer (2004), Yalcin \& Karahan (2007), Calogero (2009), Trudel (2010), Oprisan \& Cristae (2012), Vibha, Saddichha, Khan \& Akhtar (2013), Karimi (2007), Banihashemi (2011), Kavianpour (2012) and Mahini (2012). According to these studies, the variable of cognitive emotion regulation increases marital adjustment and it has

\section{REFERENCES}

1. Adibnia, Naeimeh. (2012). The mediator role of document styles related to personality traits and marital adjustment in high school teachers. Master's thesis. Marvdasht Azad University.

2. Banihashemi, Nazanin, Askari, Karim, Yarmohammadian, Ahmad (2011). The impact of emotional intelligence and life skills training on marital adjustment of young couples. Knowledge and research in applied psychology, 2, 128

3. Hassanshahi, Mahboubeh (2000). Investigation of the relationship between control focus and marital adjustment in practitioner women in the education of the city of Shiraz. Master's thesis. Faculty of psychology and educational sciences, University of Isfahan.

4. Khanzadeh, Ali, Marefat, Hamideh, Hejazi, Bagher, Jafari Kandovan, Gholamreza (2007). The relationship of emotional intelligence and assertiveness with the oral participation of English language learners. Journal of foreign languages research, 38, 19-41.

5. Darvizeh, Zahra, Kahaki, Fatemeh, (2008). Investigation of the relationship between marital adjustment and psychological well-being. Women studies, 6 (1), 91-104.

6. Samani, Siamak; Sadeghi, Ladan (2010). The adequacy of psychometric indices in cognition and emotion regulation questionnaire. Journal of psychological methods and models, 1, 38-48.

7. Ghafrani, Samarbigom (2012). Investigation of the mediating role of cognitive emotion regulation for variables of interpersonal problems and sleep quality in parents of school students in the city of Shiraz. Master's thesis. Counselling psychology. Marvdasht Azad University.

8. Fani, Darioush (2009). Investigation of the relationship between cognitive emotion regulation strategies, also been approved that assertive people have higher levels of marital adjustment, which corresponds to the results of the present study. To explain these results, we should refer to the theoretical foundations of research variables that include self-assertiveness, cognitive emotion regulation and marital adjustment. Cognitive emotion regulation includes 9 subscales; some of these subscales refer to cognitive positive emotion regulation and some of them refer to cognitive negative emotion regulation. The positive factors reduce the importance of a horrible event by an individual through the development and extension of the individual's perspective, positive refocusing on thinking about joyful and welcoming issues instead of thinking about the actual event, positive evaluation of thoughts on the accession of positive connotations to the event in terms of personal growth, acceptance of the event situations and satisfaction on what has happened, planning and thinking about how to deal with these accidents and incidents and what steps can be taken in this way.

\section{Research suggestions}

According to the results of the present study, it is recommended for counselling centers to use workshops and trainings of assertiveness to promote the marital adjustment of couples. Besides, family welfare counselling centers should implement positive emotion regulation trainings to enhance the marriage compatibility of couples.

social skills and aggression in elementary school students in the city of Shiraz. Master's thesis. University of Shiraz.

9. Kavianpour, Maryam (2012). The effectiveness of emotion-focused consulting group therapy on cognitive emotion regulation of couples in the city of Shiraz. Master's thesis.

10. Karimi, Ahmad (2007). The impact of individual psychological adjustment on marital adjustment. Journal of Law and Justice, 9.

11. Mollazadeh, Javad (2002). Coping styles and marital adjustment in children of martyrs, Tarbiat Modarres University. Master's thesis.

12. Mahini, Shahram (2012). Comparison of cognitive emotion regulation strategies and thought-action strategies in the couples demanding divorce and ordinary couples with the moderating role of gender. Quarterly of family psychotherapy, 3, 60-74.

13. Aldao, N. Nolen. Hoeksema, S. (2010). Specificity of cognitive emotion regulation strategies: transdiagnostic examanition. Behavioral Research and Therapy, 48, 974-983.

14. Alloy, L. B. \& Riskinnd, J. H. (2006). Cognition vulnerability and emotional disorders. New Jeersy. Lawrence Erlbaum Associats.

15. Calogero, Rachel, M. J. (2009). Potential implications of the objectification of women's bodies for women's sexual satisfaction. Body Image, 2, 145-148.

16. Galhardo, Ana Gunha, Matos, M. (2013). The meditor role of emotion regulation process on infertility related stress. CINETCC-fculty of psychology and educational science of the University of Coimbra. DOI: 10880-910.

17. Granefski, N., Kraaij, V. and Spinhoven, P. H. (2001). Negative life events in cognitive emotion regulation and depression. Personality and individual differ- 
ences, 30, 1311-1327.

18. Granefski, N., Kraaij, V. (2006). Relationships between cognitive emotion regulation strategies and depressive symptoms and comparative study of five specific samples. Personality and Individual Differences, 40, 1659-1669.

19. Granefski, N., Kraaj, V., Spinhoven, P. H. (2002). GERQ:Manual for the use of cognitive emotion regulation question naïve. Dates Leiderdorp. The Netherlands.

20. Hulbert, D. F., Apt, C., Robehl, S. M. (1993). Key variables to understanding female sexual satisfaction: an examination of women in non-distressed marriage. Journal of sex and marital therapy, 19(2), 156-162.

21. Jerman, F., Linden, M. F., Acremontand, M. \& Zermatten, A. (2006). Cognitive emotion regulation Questionnaire. Confirmatory factor analysis and psychometric properties of the French Translation-European. Journal of psychological Assessment, 22, 126-131.

22. Keicoat, G. \& Janice, K. (2005). Hostile marital interaction. Archive General psychology, 62, 112-122.

23. Ongen, D. E. (2010). Cognitive emotion regulation in the prediction of depression and submissive behavior. Gender and grade level differences in Turkish adolescents. Procedia and Behavioral sciences, 9, 1516-1523.

24. Oprisan, E. \& Cristae, D. (2012). A few variables of influence in the concept of marital satisfaction. Journal of social and Behavioral science, 33, 468-472.

25. Perlman, D. (1987). Further reflection on the present state of Loneliness research. In M. Hoja \& R.
Ctandall (Eds.). Loneliness: theory research and Applications. Ssn Rafael Select press.

26. Rios, C. X. (2010). The relationship between premarital expectation and marital satisfaction. MA thesis. Department of family and marriage research. Utah state university.

27. Rosen, J. R., Myers, J. E. \& Hattie, J. A. (2004). The relationship between marital characteristics. Marital interaction processes and marital satisfaction. Journal of counselling and development, 82, 58-68.

28. Szczygie, D., Buczny, Y. \& Bazinskar, C. (2012). Emotion regulation and emotional information processing the moderating effect of emotional awareness. Personality and Individual Difference, 52, 433-437.

29. Trudol, G. (2010). Goldfarb marital and sexual functioning and dysfunctioning depression and anxiety. Sexology, 3,137-142.

30. Vibha, P., Saddichha, S., Khan, N., Akhtar, S. (2013). Quality of life and marital adjustment in remitted psychiatric illness: an exploratory study in a rural setting. Journal of new mental disorders, 201(4), 334-338.

31. Yalcin, B. M. \& Karahan, T. F. (2007). Effect of a couple communication program on marital adjustment. Journal of the American Board of family Medicine, 20(1), 36-44.

32. Zlomke, K. R. \& Hahn, K. S. (2010). Cognitive emotion regulation strategies of gender difference and associations to worry. Personality and Individual Differences, 48(4), 400-413.

$$
\begin{array}{r}
\text { Мабуб Размюй, } \\
\text { психологічна служба, Ісламський університет Азад, } \\
\text { Зхале Рефах, } \\
\text { доктор психологічних наук, } \\
\text { психологічна служба, Ісламський університет Азад, } \\
\text { Надер Сораб, } \\
\text { доктор психологічних наук, факультет психологї,, } \\
\text { Ісламський університет Азад, } \\
\text { філіал Марвдашт, м. Марвдашт, Іран. }
\end{array}
$$

\section{ДОСЛІДЖЕННЯ ОПОСЕРЕДКОВАНОГО ВПЛИВУ САМОВПЕВНЕНОСТІ} ОСОБИСТОСТІ НА КОГНІТИВНУ ЕМОЦЙНУ РЕГУЛЯЦЮЮ ТА ПОДРУЖНЮ СУМІСНІСТЬ

Відомо, що на сімейне благополуччя та задоволеність подружнім життям впливають емоції, причому як позитивні, так і негативні. Згідно з деякими дослідженнями, задоволення сімейним життям має зворотну кореляцію з невротичною поведінкою. Окрім цього, доведено, що депресія, тривога та гнів мають негативний ефект на сприйняття подружнього життя як жінками, так і чоловіками. На противагу цьому, вміння спілкуватися належним чином, висока самооцінка чоловіка і жінки позитивно впливають на подружню адаптацію. Було проведено дослідження 3 метою вивчення ролі самовпевненості у співвідношенні між когнітивною емоційною регуляцією та подружньою сумісністю. В експерименті взяли участь 205 респондентів (165 чоловіків і 38 жінок) віком від 22 до 55 років, яких було відібрано кластерним методом. Для збору інформації використовувалися такі опитувальники: Опитувальник на визначення самовпевненості (Shilton and Broughton, 1993), Опитувальник на визначення когнітивної емоційної регуляції (Garnefski, 2001) та Шкала визначення подружньої сумісності (Spanier, 1976). Результати дослідження підтвердили опосередкований вплив змінної «самовпевненість» на когнітивну емоційну регуляцію та подружнє сумісництво. Когнітивна позитивна і негативна емоційна регуляція через самовпевненість має безпосередній та опосередкований вплив на подружнє сумісництво. За результатами проведеного дослідження запропоновано деякі рекомендації: консультаційним психологічним центрам слід запроваджувати та проводити семінари і тренінги, спрямовані на розвиток впевненості в собі подружніх пар, щоб сприяти налагодженню їхніх стосунків. Крім того, також рекомендується центрам сімейного консультування впроваджувати тренінги з формування позитивної емоційної регуляції для підвищення подружньої сумісності пацієнтів.

Ключові слова: самовпевненість, когнітивна емоційна регуляція, подружня сумісність.

Submitted on January, 20, 2017 